\title{
Assessing the Role of Students and Textbook on the Problems of Writing Effective Paragraph
}

\author{
Merga Gemeda Abaye*
}

\author{
Department of Oromo Language and Art Studies, Institute of Language Studies and Journalism, \\ Wollega University, Post Box No: 395, Nekemte, Ethiopia
}

\begin{tabular}{lll}
\hline & Abstract & Article Information \\
\hline This research focused on assessing the problems of students in writing effective paragraph. Its & Article History: \\
main objective is an assessment of the problems of students and text book on writing effective & Received :11-04-2015 \\
paragraph. In the research mixed approach research design was used. The sampling technique & Revised $: 26-06-2015$ \\
used was random stratified, and $90(30 \%)$ of participants were selected. The researcher used & Accepted :28-06-2015 \\
\cline { 2 - 2 } questionnaire, test, observation, interview and analyzing student's text book. The finding & Keywords: \\
indicated that the students are not practicing to write effective paragraph. The mean value of & Paragh \\
students on paragraph writing test is below 50. This shows that there is a serious problem. & Effective \\
Paragraph writing tasks which are included in student's text book only 13(14.44\%). In general, & Writing \\
students have many problems in writing effective paragraph; as they are not practicing & Problem \\
paragraph writing and the limited number of paragraph writing tasks is used in student's text & *Corresponding Author: \\
book. As the problem is widely observed, it invited students, teachers, Oromia educational & Merga Gemeda Abaye \\
bureau and other concerned bodies to device mechanisms of alleviation strategies & E-mail: \\
Copyright@2015 STAR Journal, Wollega University. All Rights Reserved. & dilalloo@yahoo.com \\
\hline
\end{tabular}

\section{INTRODUCTION}

The base for composition writing began in $1960^{\text {th }} \mathrm{C}$ concerning on the development of first language writing. At that time, study on organization, composition writing, and linguistics was started (Ferris \& Hedgcock, 2005). However, there was no guideline of composition writing until 1980's. At the beginning and the mid of $20^{\text {th }} \mathrm{C}$ guideline for writing composition had been occurred as education policy (Ghabol et al., 2012). Its aim was to let students from lower to higher level of U.S. organize text by analyzing different writings (Sun et al., 2009).

In 1960's, 1970's and 1980's education policy and higher standard researchers were used writing composition of first language (Badger \& White, 2000). The process of writing which was begun during this time gave due attention for individual creative writing (Hasan et al., 2010; Nunan, 1999). The focus of this approach was to solve problems, to observation, to explaining or to describe things in writing, the idea of redundancy and all rounded writing composition (Ferris \& Hedgcock, 2005).

As Susser (1994) states, at the beginning of $20^{\text {th }} \mathrm{C}$ those who used the process of paragraph writing in $1^{\text {st }}$ language as source were the follower of John Dewey "learning is a process". Due to this, starting from that time was being raised as a theory debate in methods of teaching writing and conducting research. Concerning the process of writing research in $1^{\text {st }}$ language to teach paragraph composition in English, the first guideline was describing the process of writing (Zamel, 1983).
Different researchers used the word composition and writing interchangeably in their studies. For example, scholars who were the advocate of "writing represents spoken words" (Checkett et al., 2010; Brown, 2001; Wyrick, 1990). The success of writing is determined by pre writing, while writing and evaluation .Therefore, the process of writing is a process of composing; a result of writing is a result of composition (Zamel, 1983). In her study she used the process of composing. This, writing was a general term used for composing similar ideas together and it was not different from the term composing (Hageman, 2003).

According to Ferris and Hedgcok (2005), writing is an organization of ideas, practice of words and arranging the structure of tasks. Students are learning while they are doing such activities. Besides, as Abdulwahed and Ismail (2010), writing is a basic measurement through which the students are evaluated in their learning process. Similarly, writing is a means by which the student reveals a sense of ones personality gets fair perception and visualizes the picture of objects (Darus, 2012).

Yakhontova (2003) states that, writing is a process of recording complicated ideas of the society at large in an organized manner. In this case, diction, spelling and giving due consideration to audiences are important. Due to this fact, interest based tasks are the base for the success of the students' writing. In line with this, Lillis (2001) report, writing are an art through which ideas and spoken words are put in written form. She underlines that 
Merga Gemeda Abaye

the above idea is the key point of learning as it is the base for the knowledge of common language structures and the systematic arrangement of words. In general it is composing a single sentence, concerned with the production of extended texts.

According to Voon (2007), students take notes and express their feelings in written form if they have the skills of writing. Supporting this, Langan (2010) affirm that, having a potential in writing skills requires giving due attention to the structure of writing starting from spelling to paragraph. Hence, writing is the means by which message is conveyed, and it needs quality and effectiveness at all levels of writing.

\section{METHODOLOGY}

\section{Description of the Study Area}

This study focused on Ifa Secondary School grade $9^{\text {th }}$ which is found in East Wollega, Diga Woreda in Ifa town which is $12 \mathrm{kms}$ from Nekemte. In the town one Preparatory and one Secondary School are found. The study used a mixed approach research method. According to Creswell (2012), mixed approach (quantitative and qualitative) is used to differentiate the problem of a study by gathering data and analyzing it.

\section{Research Design}

According to Creswell (2012) and Dornyei (2007), the design of the study is based on descriptive data analysis. Besides, it is used to triangulate the data obtained through different tools. Hence, the sampling technique used to select the School, grade level and section is purposive sampling. Then, $50(16.67 \%)$ male and $40(13.33 \%)$ female students were selected by stratified sampling technique.

\section{Data Analysis and Interpretation}

The participants of the study were both teachers and students from Ifa secondary school. The quantitative data is analyzed using SPSS; it is specifically analyzed using mean value and variance (Neuman, 2007),

$$
\bar{X}=\frac{\sum_{i=1}^{n} f_{i} Y_{i}}{\sum_{i=1}^{n} f_{i}}
$$

Where $\mathrm{Y}_{\mathrm{i}}=$ the class mark of the $\mathrm{i}^{\text {th }}$ class and $=$ the frequency of the $i^{\text {th }}$ class
Sci. Technol. Arts Res. J., April-June 2015, 4(2): 272-277

The other analyzing procedure used is bi- variation (Dornyei, 2007). This is used to crosscheck the relationship between dependent and independent variables or the reliability of variables (Pearson Chisquare test). The significance level given for each items is $\geq 0.05$. The main reason of using Chi-square is to keep the relationship of dependent and independent variables.

$\chi^{2}=\sum_{i=1}^{r} \sum_{j=1}^{c}\left[\frac{\left(O_{i j}-e_{i j}\right)^{2}}{e_{i j}}\right] \sim \chi^{2}$ with $(r-1)(c-1)$ deg ree of freedom

Where $\mathrm{O}_{\mathrm{ij}}=$ the number of units that belong to category $i$ of $A$ and $j$ of $B$.

$e_{i j}=$ Expected frequency that belong to category $i$ of $A$ and $\mathrm{j}$ of $\mathrm{B}$ and $e_{i j}$ is given by

$e_{i j}=\frac{R_{i} \times C_{j}}{n}$

Where $\mathrm{R}_{\mathrm{i}}=$ the $\mathrm{i}^{\text {th }}$ raw total

$C_{j=}$ the $j^{\text {th }}$ column total.

$n=$ total number of observation

\section{RESULTS}

Reasons for Paragraph Writing Problems in Afan Oromo

Concerning the problems of students in paragraph writing, in Afan Oromo and to check the practices, it was shown in the following table.

Table 1: Making practice

\begin{tabular}{cccc}
\hline Variables & Kay-square & $\begin{array}{c}\text { Degree of } \\
\text { freedom }\end{array}$ & P-value \\
\hline $\begin{array}{c}\text { Making } \\
\text { adequate practice }\end{array}$ & 5.10 & 12 & 0.95 \\
\hline \multicolumn{4}{c}{ P-value $>0.05$ or $p=0.955$}
\end{tabular}

The relationship between being interested in writing different texts and writing paragraph was observed. That is the significance level of students in practicing paragraph writing is greater than 0.05 ; this shows that the variables do not have relation. In other word, since the $p$ value is greater than 0.05 , there is no significant relation in the hypothesis of dependent and independent variables. This shows the students' interest of writing different texts in Afan Oromo does not show that their practice of writing effective paragraph. As the data from interview shows the reason for this lack of awareness creation, materials, not getting adequating knowledge from teachers.

Table 2: The content of paragraph writing activities in students' text book

\begin{tabular}{|c|c|c|c|}
\hline Level of Paragraph writing activities & Liker Scale & № & $(\%)$ \\
\hline level of frequency of (paragraph & Few & 9 & 15 \\
\hline \multirow[t]{3}{*}{ Writing) Activities in students' texts book } & A few & 34 & 56.67 \\
\hline & Average & 14 & 23.33 \\
\hline & Many & 3 & 5 \\
\hline \multicolumn{2}{|l|}{ Total } & 60 & 100 \\
\hline Level of motivating (paragraph & demotivating & 1 & 1.67 \\
\hline \multirow[t]{4}{*}{ Writing) Activities in students' texts book } & Less motivating & 11 & 18.33 \\
\hline & Average & 24 & 40 \\
\hline & Motivating & 19 & 31.67 \\
\hline & Highly motivating & 5 & 8.33 \\
\hline \multicolumn{2}{|l|}{ Total } & 60 & 100 \\
\hline level of difficulty of (paragraph & Easy & 4 & 6.67 \\
\hline \multirow[t]{4}{*}{ Writing) Activities in students' texts book } & Very easy & 5 & 8.33 \\
\hline & Average & 34 & 56.67 \\
\hline & Difficult & 13 & 21.67 \\
\hline & Very difficult & 4 & 6.67 \\
\hline Total & & 60 & 100 \\
\hline
\end{tabular}


Merga Gemeda Abaye

According to the data from the table, $34(56.67 \%)$ says a few $14(23.33 \%)$ that there are average tasks, and $9(15 \%)$ of them responded that the task is occasionally used. Concerning the tasks which motivate students to write paragraph the data were gathered on how much the writing tasks in students' text book encourage students to write paragraph. Based on this, $24(40 \%)$ of them responded that the tasks are averagely motivating, $19(31.6 \%)$ of them said it is motivating, $11(18.33 \%)$ of the respondents said that the tasks are not this much motivating, $5(8.33 \%)$ are not motivating to write paragraph.

To elicit information on whether or not the purposes of paragraph writing included in text books match with students' level, questions were asked. Accordingly, the contents of writing paragraph is moderate for $34(56.67 \%)$ difficult for $13(21.67 \%)$, very easy for $5(8.33 \%)$, very difficulty for $4(6.67)$, and easy for $4(6.67 \%)$ number of the students.
Sci. Technol. Arts Res. J., April-June 2015, 4(2): 272-277

In general, the responses of the students depicted that the number (amount of paragraph writing activities in the text books are few) not optimum 34(56.67\%). In the same way, the level of difficulty of the paragraph writing activities is moderate as, $34(56.67 \%)$ claimed. In line with this, $24(40 \%)$ of the respondents claimed that the activities moderately motivate students to practice paragraph writing.

\section{Content of Paragraph Writing in Students' Text Book}

According to Al-Ghazon's and Smadin (2013) text book analysis incorporates constituents of words, concepts, themes, paraphrases, sentences, paragraphs, etc presented in the text. Based on this, the contents of writing paragraph activities presented in Afan Oromo text books of grade 9 is analyzed as follows. The book has 18 (eighteen) chapters/ units presented in 181 pages. The researcher attempted to look at types of topics for paragraph writing, kinds of instruction given, processes of writing paragraph, the magnitudes of writing activities etc presented in each paragraph.

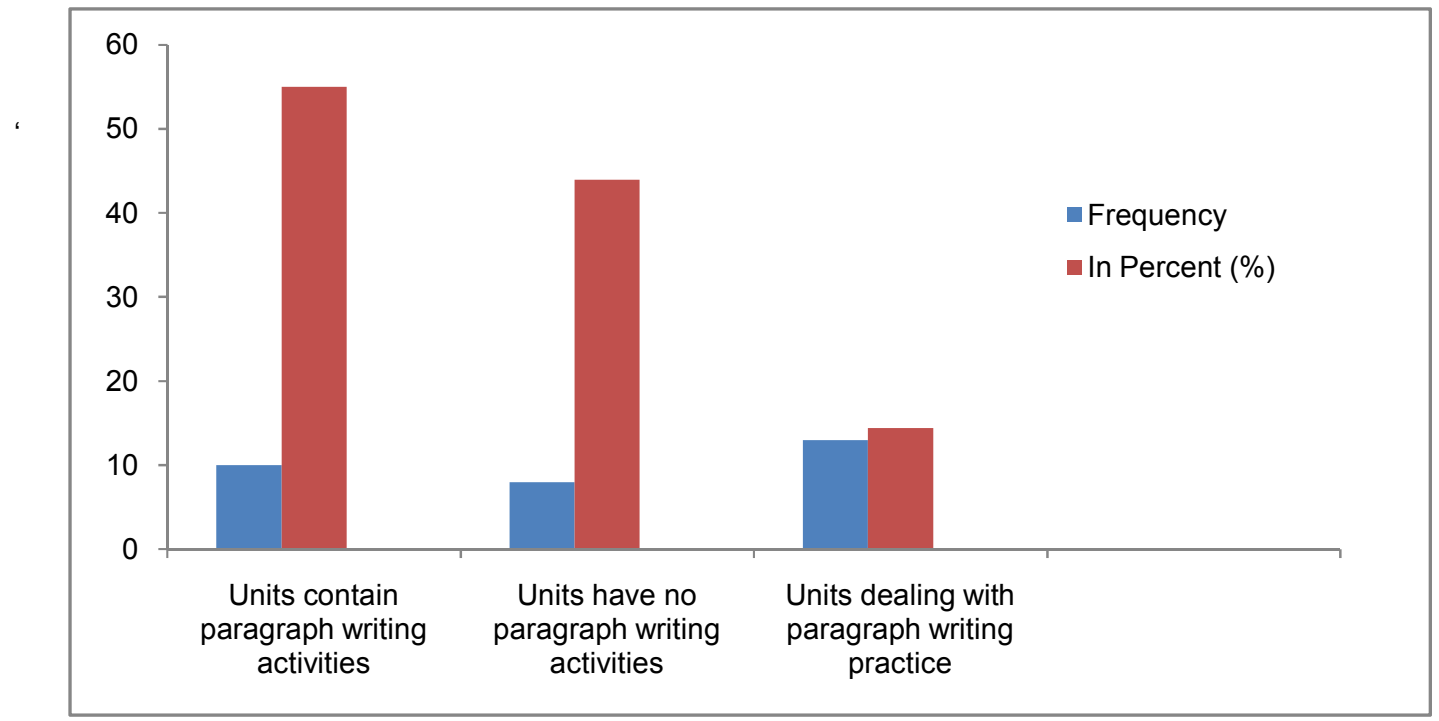

Figure 1: contents of paragraph writing including in students' text book.

From the total of 18 units of Afan Oromo text book grade $9,10(55 \%)$ units contain paragraph writing activities, and the remaining $8(44 \%)$ units have no paragraph writing activities. 90 exercises are presented in the entire text book. From this exercises only 13(14.44\%) of them deal with paragraph writing practice.
The given instruction to practice a paragraph writing contained in the units evaluated, is indicated in the following table 3 .

Table 3: Instruction given for paragraph writing

\begin{tabular}{lcc}
\hline \multicolumn{1}{c}{ Instruction given } & No & (\%) \\
\hline Constructing body of a paragraph & 1 & 7.69 \\
Write once life story & 1 & 7.69 \\
Writing letter & 1 & 7.69 \\
Starting in topic sentence & 2 & 15.38 \\
Write different types of paragraph & 2 & 15.38 \\
Usage of punctuation mark in paragraph & 3 & 23.07 \\
Writing a paragraph based on the data from table, chart and format & 3 & 23.07 \\
Writing creative based paragraph & 4 & 30.76 \\
Write a paragraph on selecting topic & 0 & 0 \\
Constrict a paragraph following paragraph structure & 0 & 0 \\
Finalize a paragraph & 0 & 0 \\
Write a paragraph depending on the characteristics of a paragraph & 0 & 0 \\
\hline
\end{tabular}




\section{Merga Gemeda Abaye}

As can be seen from the above table, the instruction given for out lining, constructing bodies of a paragraph, writing letter, writing one's life history, is only aggregate $4(30.76 \%)$. And the instruction given to write paragraph using punctuation marks and constructing a paragraph from tables, charts and formats is $6(46.14 \%)$.

On the other hand, there is no any instruction given on how students choose topics, construct a paragraph following paragraph structures, finalize a paragraph, and write a paragraph depending on its characteristics.

In general, it is possible to conclude, from this text book analysis that the instruction on how to practice
Sci. Technol. Arts Res. J., April-June 2015, 4(2): 272-277

paragraph writing and the numbers of exercises given in the text books to let students practice writing a paragraph is not enough.

\section{Paragraph Writing Test}

Paragraph writing test or assessment was conducted on 20 students. The questions were produced and asked in series according to Quellmalz and Burry, (1983), and the assessments were corrected or marked. After correcting the points were described starting from the least mark, average, high mark, and the difference among the marks.

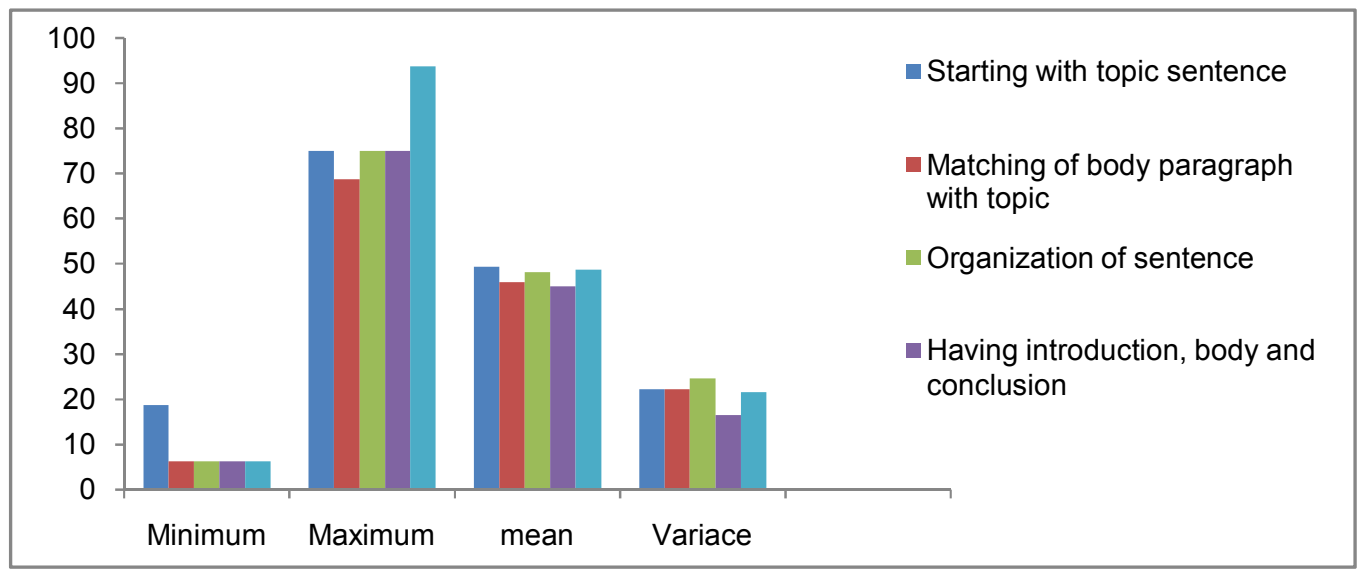

Figure 2: descriptive statics: marks on idea Organization.

To see if students started writing with topic sentence on the paragraph writing exam, the result from least to high was between 18.75 to 75 with an average 49.38 . The difference is calculated as 22.21 .

Regarding the mismatch between body and conclusion of a paragraph with the topic sentence, the mark was distributed between 6.25 least and 93.75 maximum with the mean score of 48.75 and the difference is 21.61 . Coming to organization of sentences in a paragraph, the marks of the students were between 6.25 to 75 with the mean score of 48.12 . The variance of this score is calculated to 24.68. Concerning the match between topic sentence and supporting sentences, the mark of students from least to high falls between 6.25 to 68.75 . The mean score and variance of this mark is 45.94 and 22.24 respectively.

Finally, the students achievement on whether the paragraph has topic sentence, body, and concluding sentence or not, their mark from least to most is 6.25 to 75 and its average (mean) is 45 with the variance of 16.65 .

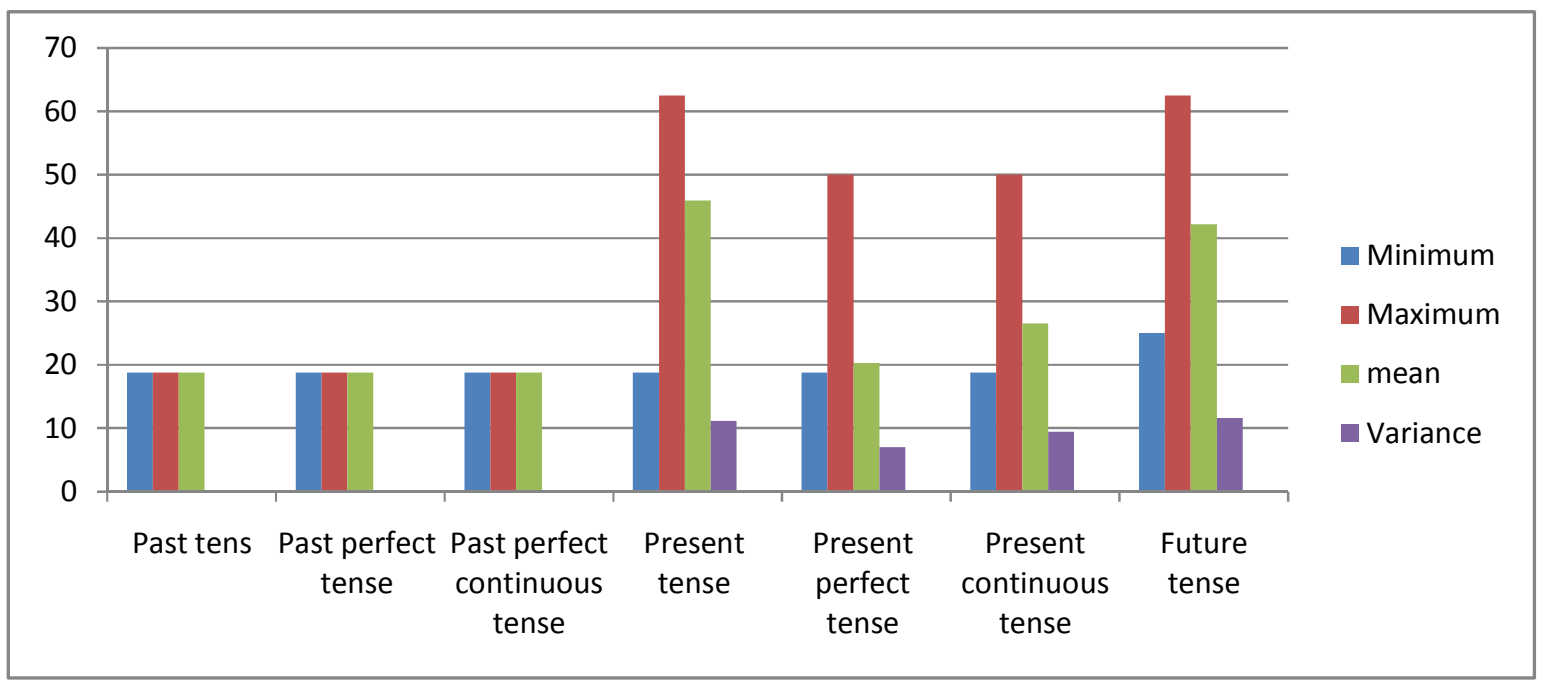

Figure 3: descriptive statics: marks on writing correct tense 
Regarding the students mark /point on the use of past tens, past perfect tense and past perfect continuous tense, their achievement was between 18.75 to 18.75 with the mean score of 18.75 . On this point, no variance was observed.

Coming to student's achievement on the use of present tense from minimum to maximum it was 18.75 to 62.5 with the mean value of 45.94 and the variance is 11.16. Similarly, students' achievement on the use of future tense lies between 25 and 62.5. The mean and the variance of this score, one after the other was 42.19 and 11.63. In the same was the students' mark on the use of present continuous tense was 18.75 to 50 from minimum to maximum and the mean and variance of the same point were 56.26 and 9.48 respectively. Finally, the students mark on present perfect tense fall between 18.75 and 50 with the mean of 20.31 and variance of 6.98 .

From the above result, dealing with students' achievement on paragraph writing, students' ability of spelling and layout, developing the topic sentence (idea), organizing ideas and sentences, punctuation marks, and tenses etc summed up and came up with the mean score of less than 50 . This reveals that students have problems of paragraph writing.

\section{DISCUSSION}

The objective of this study was to analyze the problem students get to write an effective paragraph. Therefore the basic question this research was supposed to answer was: What are the reasons that make students not to write an effective paragraph? Do the activities help students to practice paragraph writing adequately in Afan Oromo text book?

Accordingly, there is no relationship between the variables liking to write different pieces of writing in Afan Oromo and practicing writing a paragraph at the significance level of 0.05 . This means, liking writing in Afan Oromo does not indicate that the students practice writing a paragraph. Cheng and Dornyei (2007), Loa and Hyland (2007), and Raby (2007) claimed that, students' writing ability (capacity) not only depends on liking the literal language but also on motivating and giving opportunity for students to practice writing. This can help them construct an effective writing (text). Thus, it is realized that liking the language that one writes does not mean writing an effective piece of writing.

According to the Afan Oromo text book, when the number of activities are many they help the student practice paragraph writing; whereas when the number of activities are few, they can be a reason for the student lack of the writing ability (Boardman \& Frgdenbery, 2008). This shows that encouraging students is an average and this has an impact on paragraph writing. The level of difficulty of the activities incorporated was also average which is supported professionally.

In addition to this, it was analyzed that from 18 (eighteen) units of the text book, only $13(14.44 \%$ ) units would provide activities to help students practice writing paragraphs. This can negatively affect the students' writing ability.

In general, the test (examination) given for students to see the ability they have to construct an effective paragraph was corrected. The data showed that the mean for writing using correct spelling, content, organization, logical sequence of ideas, usage of punctuation marks and tenses was below 50. Regarding this, Al-Buaiman (2007), conducted a study on writing an effective paragraph and found out that the problem of tenses and punctuation marks was similar to the finding of this research. However, the problem students have to write an effective paragraph in Afan Oromo is vast.

\section{CONCLUSIONS}

This study was conducted on students' problems writing effective paragraph of grade 9 Ifa secondary school which came up with the following conclusion. Afan Oromo is used as a medium of instruction for Oromo students. They may consider this language as it is easy for writing. On top of this, the study was conducted to see how match students practice paragraph writing in their first language (Afan Oromo).

However, though they like to write in Afan Oromo, the finding reveled that students could not write effective paragraph. The major causes for their failure to write effective paragraph are: lack of supportive materials on writing, lack of knowledge and skill from teachers, and shortage of libraries are some among the problems listed by respondents.

In addition, the way the text books were designed also affected students' writing. Text book should be designed in such away that students get chance to practice by themselves than observe information from teachers. Accordingly, it is inferred from the data that the number of exercise or activities in the text books are minimal. The number of exercises in the text books and instruction under each exercises that deal with paragraph writing had impact on students' ability to write effective paragraph. Finally, students were evaluated as per the criteria of paragraph writing and the result depicted that the effectiveness of the paragraph written by the students was computed with the mean score of less than 50 . This shows that students have problem of writing effective paragraph.

\section{Acknowledgements}

I am indebted to Wollega University for the inspiration and practical help of this research. Thanks also to Dr. Zeleke Teshome, Teferi Terefe and Endalew Alemayehu whose comments on my paper were so instructive.

\section{Conflict of Interest}

Conflict of interest none declared.

\section{REFRENCES}

Abdulwahed, S. and Ismail, A. (2010). Exploring students' perception of ESL writing. Journal of English Language Teaching 4(2): 73.

Al-Buainain, H.A. (2007). Researching types and causes of errors in Arabic speakers' writing" in Midraj, S. Jendli, A \& Sellami (Eds.). (2007). Research in ELT Issues. TESOL. Arabia: Dubai. UAE. (pp. 195-224).

Al-Ghazo, A. and Smadi, O.M. (2013). A content analysis of the English reading text's authenticity in student's book of action pack eleven in Jordan. European Scientific Journal 9(29):1857-7881. 


\section{Merga Gemeda Abaye}

Badger, R. and White, G. (2000). A process genre approach to teaching writing. ELT Journal 153-160.

Boardman, C.A. and Frydenberg, J. (2008). Writing to communicate: Paragraph and essays. ( $\left.3^{\text {rd }} . e d.\right)$. White Plains: Pearson Education, Inc.

Brown, H. D. (2001). Teaching by principles: An interactive approach to language pedagogy. New York, NY: Addison Wesley Longman.

Checkett, G.F. and Checkett, L. (2010). The write start sentence to paragraph with professional and student readings. ( $4^{\text {th }}$ ed.). Boston: Words worth Engage, Learning.

Cheng, H. and Do"rnyei, Z. (2007). The use of motivational strategies in language instruction: The case of EFL teaching in Taiwan. Innovation in Language Learning and Teaching 1(1): 153-174.

Creswell, J.W. (2012). Educational research. Planning, conducting, and evaluating quantitative and qualitative research. ( $4^{\text {th }}$ ed.). New York: Pearson Education, Inc.

Darus, S. (2012). ESL students' attitude, learning problems, and needs for online writing. Journal of Language Studies 12(4): 1089-1101.

Dornyei, Z. (2007). Research method in applied linguistics. Quantitative, qualitative and mixed methodology. Oxford: Oxford University Press.

Dornyei, Z. (2001). Motivational strategies in language class room. Cumbredge: Cumbredge University Press.

Ferris, D. and Hedgcock, J. (2005). Teaching ESL composition. New York, NY: Taylor \& Francis Group.

Ferris, D.R. (2003). Response to student writing: Implications for second language students. Mahwah, NJ: Lawrence Erlbaum Associates.

Ghabol, N., Edwina M., and Kashef, H.S. (2012). Investigating Malaysian ESL students' writing problems on conventions, punctuation, and language use at secondary school level. Journal of Studies in Education 2(3): 130-142

Hageman, J.A. (2003). Balancing content and form in the writing work shop. English Journal 92(3): 73-79.

Hasan, K., and Akhand, M.M. (2010). Approaches to writing in EFL/ESL context: Balancing product and process in writing class at tertiary level. Journal of NELTA 15(1-2): 77-88.
Sci. Technol. Arts Res. J., April-June 2015, 4(2): 272-277

Langan, J. (2010). Exploring writing sentences and paragraphs. (2nd. ed.). New York: McGraw-Hill Companies, Inc.

Lillis, Th. M. (2001). Student writing. Accesses, regulation, desire. Student writing in higher education. New York: Rout ledge.

Loa, J. and Hyland, F. (2007). Enhancing students' engagement and motivation in writing: The case of primary students in Hong Kong. Journal of Second Language Writing16(2): 219-237.

Neuman, W.L. (2007). Basic of social research. Qualitative and quantitative approach. ( $2^{\text {nd }}$. ed. $)$. New York: Pearson Educational Inc.

Nunan, D. (1999). Second language teaching and learning Boston: Heinle \& Heinle Publishers.

Quellmalz, E.S., and Burry, J. (1983). Analytic scale for student's expository and narrative writing skills. Los Angeles: Center for the study of Evaluation UCLA Graduate School of Education.

Raby, R. (2007). A triangular approach to motivation in computer assisted autonomous language learning (CAALL). European Association for Computer Assisted Language Learning Recall 19(2): 21-38.

Sun, Ch., and Feng, G. (2009). Process approach to teaching writing applied in different teaching models. English Language Teaching 2(1): 150-155.

Susser, B. (1994). Process approaches in ESL/EFL writing instruction." Journal of Second Language Writing 3(1): 3147.

Voon Foo, C.T. (2007). The effects of the process-genre approach to writing instruction on the expository essays of ESL students in a Malaysian secondary school. Malaysia: Penang.

Wyrick, J. (1990). Steps to writing well. A concise guide to composition. ( $4^{\text {th }}$ ed.). USA: The Dryden Press.

Yakhontova, T. V. (2003). English academic writing: For students and researchers. USA: New York: Longman.

Zamel, V. (1983). The composing processes of advanced ESL students: Six case studies. TESOL Quarterly 117(2): 165-178. 